\title{
教育講演 II
}

\section{血液透析器の改良}

阿岸 鉄三

東京女子医科大学腎臟病総合医療センター

\section{〈要昌〉}

ごく最近まで人工堅臓といえば，血液透析を原理とす る血液浄化器, あるいは装置を意味していた。したがっ て，血液透析器の改良・開発は人工腎葴の歴史そのもの であった。

最初に，最近の医工学的知識からみて，血液透析器の 設計。製作の際に満なしていなければならない条件。問 題点について解説する。

I 。透析器として溶質輸送能，限外濾過能が適切でな ければならない。II。透析器材料, 血液・透析液流路の 形状が適切でなければならない。膜面積は適当に大きく， 血液充填量は少ないのが望ましい。III。有效膜面積率は できるだけ大きく，血流分布・透析液流分布が偏らない ことが求められる。

これらの観点から，過去に存在した血液透析器の問題 点と改良点とを指摘する。

はじめに

現在では腎不全患者の人工的血液浄化法には，血液濾 過・吸着昘灌流などもある。しかし、ごく最近まで人工 腎臓とい光ば，血液透析を主な原理とする血液浄化器， あるいは装置を意味していた。また，世界中に約 10 万人 いると推定される末期腎不全患者の大部分は血液透析に よって生命を維持されている。

したがって，血液透析器の改良。開発は人工腎臓の歴 史そのものであった。

最初に，最近の医工学的知識加らみて，血液透析器の 設計の際に要求される条件や，実際の製作上の問題点に ついて述べる。次で，過去から現在までに現実に存在し た透析器のいくつかについて問題点と改良点について指 摘する。

\section{血液透析器の評侕}

1. 透析器における物質輸送

1) 溶質輸送能

透析器における溶質の除去は主に透析という物理的現 象による。生体のホメオスターシスを維持できるような 尿毒症性溶質除去能が必要である。一般には、クレアラ ンス、またはダイアリザンスとして評価される。

\section{2) 限外滤過能}

透析器による生体からの除水は，主に限外滤過による。 限外德過には透析器膜の透水性拉よび膜圧が関係する。 適切な除水能が必要である。

2. 透析器設計の一般的要件

1) 透析器の材料

強度・耐久性とともに血液に直接接触しても無害な材 料でなければならない。

2) 血液・透析液流路の形状

角ばった流路，溶血を起こすような流路の形状は避け ねばならない。

3) 機械的問題

血液・透析液の漏出や透析膜の破綻などが起こらない ような配慮が必要である。

4) 透析膜面積

溶質・水分の除去には適当な膜面積が必要である。

5) 充填量

過大な血液充填量は患者の循環系に悪影響を及ぼす。 充填量の増大は危険である。

6) 血流・透析液流に対守る抵抗

過大な血流抵抗は不必要な除水をひき起こし，過大な 透析液流抵抗䚾透析液の血液側への逆限外濾過を招く可 能性がある。

3. 透析器の特殊な問題点

1) 有効膜面積

コイル型・積層型透析器では膜支持構造によって膜面 が一部覆い隠されている。一方，限外濾過のための膜压 により膜面は一部伸展し拡大する。

2）血流分布

ツインコイル型では，血液が 2 本の透析膜チューブに 均等に流れないことがある。幅広いチューブを用いてい る場合にも同様なことが起こる。中空系型では中空系束 の部分によって血流分布にかなりの偏りのあることが指 摘されている。

3）透析液流分布

多くのコイル型では、コイル型中心部には透析液が充 分に灌流していない。また，中空系束の中心部には通常 透析液が充分に流れていない。 
4) 血流・透析液流抵抗と膜圧

コイル型でコイルをきつく巻き過ぎると血流抵抗のた め不必要な限外㴧過が抗こる。密封式コイルでは透析液 流抵抗のための透析液流量を大きくすることができな い。中空系型で透析液流分布をよくしょうとしていろい ろの細工をすると，透析液側加ら血液側への限外滤過を 生じる可能性がある。

\section{個々の透析器における問題点と改良}

前述のような観点加らすると，個々の透析器には，そ れぞれの欠点が指摘される。ときには，光れはかなり重

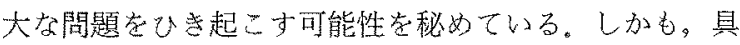
合の聴いことには，ある問題点を是正しょうとすれば， そのためにほかの矢点が現われてくることがある。しか し，現実には透析器级次第次第に改良され，物筫輸送能 はよくなり，安全性が高まっているのも事実である。 